THE S. MARK TAPER FOUNDATION IMPRINT IN JEWISH STUDIES

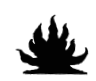

BY THIS ENDOWMENT

THE S. MARK TAPER FOUNDATION SUPPORTS

THE APPRECIATION AND UNDERSTANDING

OF THE RICHNESS AND DIVERSITY OF

JEWISH LIFE AND CULTURE 

Blood and Belief 


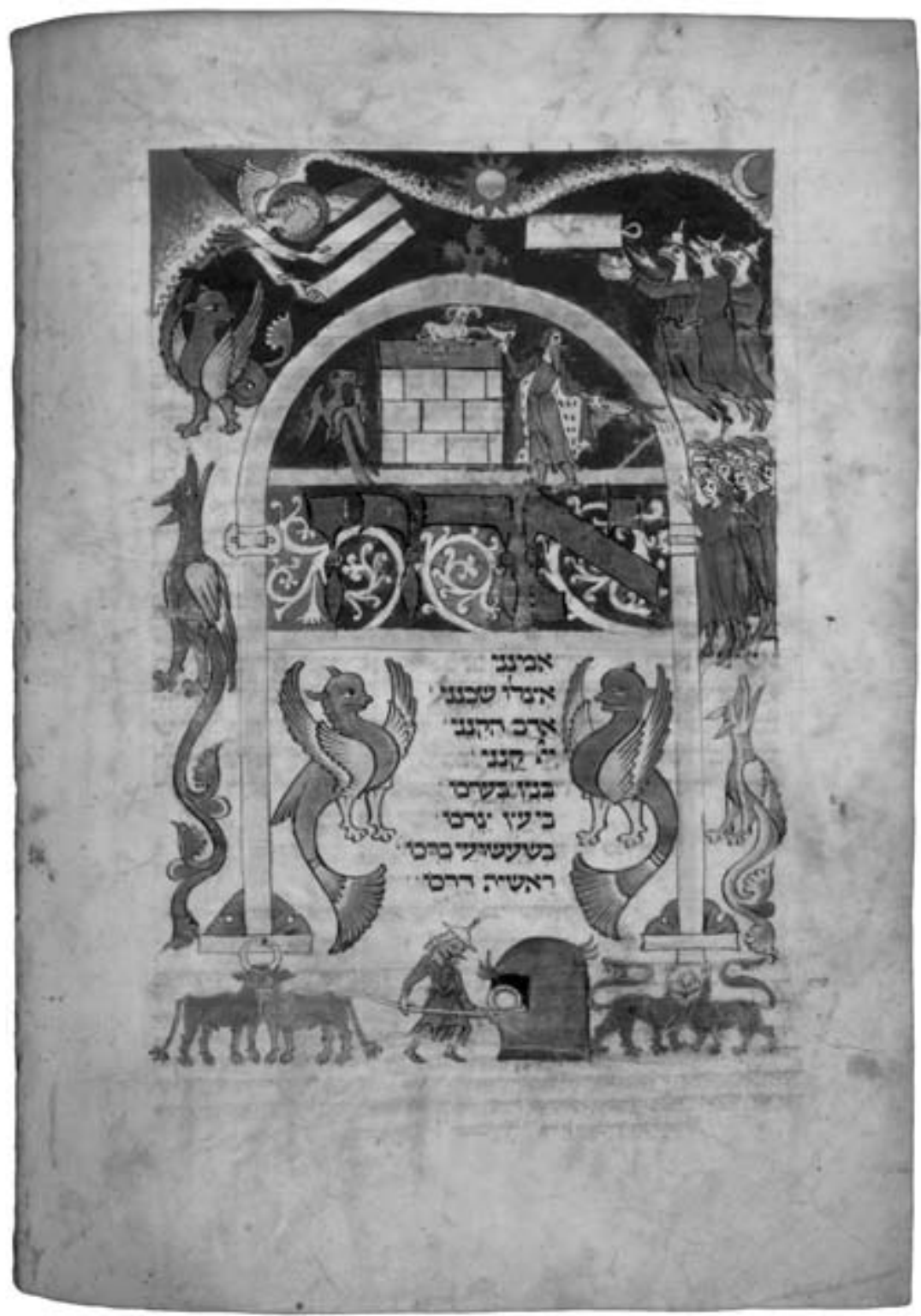

Moses throwing blood on the Israelites at the giving of the Torah on Mount Sinai. Laud Mahzor (Southern Germany, c. I290), shelf mark MS. Laud Or 321 folio I 27 verso. Reproduced by permission of the Bodleian Library, University of Oxford. 


\section{Blood and Belief}

The Circulation of a Symbol between Jews and Christians

\section{David Biale}

따

UNIVERSITY OF CALIFORNIA PRESS

Berkeley • Los Angeles • London 
University of California Press, one of the most distinguished university presses in the United States, enriches lives around the world by advancing scholarship in the humanities, social sciences, and natural sciences. Its activities are supported by the UC Press Foundation and by philanthropic contributions from individuals and institutions. For more information, visit www.ucpress.edu.

University of California Press

Berkeley and Los Angeles, California

University of California Press, Ltd.

London, England

C 2007 by The Regents of the University of California

Library of Congress Cataloging-in-Publication Data

Biale, David, I949

Blood and belief : the circulation of a symbol between Jews and Christians / David Biale.

p. $\mathrm{cm}$.

Includes bibliographical references and index. ISBN 978-0-520-25304-9 (cloth : alk. paper) I. Blood-Religious aspects-Judaism. 2. BloodReligious aspects-Christianity. 3. Blood in the Bible. 4. Blood accusation-History. 5. AntisemitismHistory. 6. Christianity and antisemitism.

7. Judaism-Relations-Christianity. 8. Christianity and other religions-Judaism. I. Title.

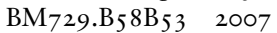

296.3 '96-dc22

2007000122

Manufactured in the United States of America

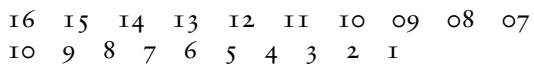

This book is printed on New Leaf EcoBook 50, a I00\% recycled fiber of which $50 \%$ is de-inked postconsumer waste, processed chlorine-free. EcoBook 50 is acid-free and meets the minimum requirements of ANSI/ASTM D5634-OI (Permanence of Paper). 
For Anina

who will find all the errors 

And [Moses] took the book of the covenant and read it to the people and they said, "All that the Lord has spoken we will do and obey." Moses took the blood and threw it on the people, saying, "Behold the blood of the covenant that the Lord has made with you concerning all these words."

Exodus 24:7-8

My flesh, which you see, becomes for me like paper and my blood like ink, where I dip my pen and write...

Romanos the Melodist (sixth century C.E.)

Of all that is written, I love only that which an individual writes with his blood. Write with blood: and you will experience that blood is spirit.

Friedrich Nietzsche, Also sprach Zarathustra 
